\title{
Accounting
}

\section{State management of import dependency and state's economic security ensuring: New analysis to evaluating and strategizing}

\section{Ruslan Lupak $^{\mathbf{a}^{*}}$, Ruslan Boiko ${ }^{\mathrm{a}}$, Marta Kunytska-Iliash ${ }^{\mathrm{b}}$, and Taras Vasyltsiv}

${ }^{a}$ Lviv University of Trade and Economics, Ukraine

${ }^{b}$ Stepan Gzhytskyi National University of Veterinary Medicine and Biotechnologies Lviv, Ukraine

cState Enterprise "Dolishniy Institute of Regional Research of NAS of Ukraine", Ukraine

\section{H R O N I C L E}

\section{Article history:}

Received: November 28, 2020

Received in revised format:

December 282020

Accepted: January 26, 2021

Available online:

January 26, 2021

Keywords:

Import dependency

State policy of import substitution

Methodology of evaluation and

strategizing

State's economic security

\section{A B S T R A C T}

The need to improve public administration of import dependency was characterized (in the example of Ukraine) and the signs of its influence and interconnection with ensuring the state's economic security are characterized. The methodological sequence of import dependency evaluation is substantiated. Using Hotelling's method of transformation (the method of principal components), the multiplicative form is presented and the integral index of import dependency of the country's economy is calculated. Harrington's interval scale is used to summarize the results of the integral evaluation of import dependency. The results of the evaluation have confirmed the high level of import dependency of the Ukrainian economy and clear tendencies for its strengthening, which is critically threatening to the country's economic security. Using the tool of multivariate dynamic regression modeling, a statistically significant correlation between the level of import dependency and the country's economic security is established. The economic and mathematical descriptive model of state management of the state's economic security is formed, which is embedded in a methodical approach to strategizing the state policy of import substitution. The purpose of the state management of import substitution, the parameters of ensuring the country's economic security agreed with it, the strategic priorities of the state policy of import substitution and the indicators of their implementation are determined.

\section{Introduction}

In order to ensure the economy's development and achieve the necessary level of the state's economic security there must be prerequisites that allow these tasks to be fulfilled. Obviously, this is the proper efficiency of the use of natural resources, the formation of a healthy competitive environment, the high investment attractiveness and innovation of production, the improvement of citizens' social security, and the development of a national economic complex with a rational relationship between all the areas of social reproduction: production, distribution and consumption. Non-progressive economies are objectively incapable of ensuring competitiveness, maintaining stability and sustainability, as it is difficult to achieve optimal ratios in the areas of production and consumption of goods (services) as the technological development of the world economy is rapid. In such circumstances, their external dependency on basic groups of goods (services), technological developments, energy resources, etc., becomes apparent. Herewith, this tendency is accelerated when structural changes and institutional reforms in the economy are low-functioning, non-systemic and have no comprehensive impact. The saturation of the market with imported products testifies to the curtailment of the investment and consumer demand for products of domestic manufacturing, narrowing of the country's industrial potential and technological development, other negative tendencies that occur in states unable to independently cover the demand of the population and enterprises in the domestic market. Thus, the signs of import dependency become apparent when in the country there are low-efficient processes of import substitution with

* Corresponding author.

E-mail address: rycj555@gmail.com (R. Lupak) 
goods of domestic production of the same quality and price characteristics, with a slow growth of domestic industrial production, and an increase in negative foreign trade balance. When in the domestic market, business entities are unable to compete with importers, import substitution is one of the important factors and tools for regulating economic development. It should be taken into consideration that an effective state policy of import substitution can not only restore production competitiveness, but also generate powerful potential for future prospects of economic development, enhance its export potential and strengthen the state's economic security. Written works on economics do not have one approach to define the generalizing level of the state import dependency and its economic security because the phenomena and tendencies which determine it vary, and their significance on the branch or spatial and territorial scale is different. Therefore, a various number of indicators are used. According to the results of their calculations, conclusions about the level of the state import dependency and its influence on the state economic security can be made.

Vlasiuketc (2016) and Liu and Rosell (2013) maintain that the investigation of the domestic market and the dependence of its development on import should be conducted using situational analysis. It should be noted that import dependency is a dynamic phenomenon and its assessment should use a number of variants. Thus, its results can help build a model of conceptual steps to solve such problems within the country and on other hierarchical management levels. Semiv and Semiv (2017) share this point of view and consider that using the method of scenario analysis and processing enables us to detect facts of maintaining unjustified high level of the economy openness according to import, which in future makes it possible to rationally determine the priorities of the development of the domestic market and stimulating import replacement. Advocates of exact calculations while assessing domestic and regional tendencies in the development of market relations and the degree of imported commodities (services) penetration, namely Günçavd and Ülengin (2017), Felbermayr et al. (2015), suggest using the method of mathematical modeling. They stress that the results of such a method can be the basis for investigating the state and tendencies of import dependency according to any approach. It goes without saying that solving the problem of import dependency is a lengthy process. That is why it is relevant to use methods which enable us to formulate objective conclusions about the state of the domestic market, the prospects of its secure development, etc. (Hrynkevych \& Vasyltsiv (2015)). It is essential to set the limit values of indicators, which make it possible to do certain assessments. It is about using the method of optimization. Ramanarayanan (2020), Ilyash et al. (2018), Cook and Watson (2011) claim that the choice and the number of indicators to assess import dependency are often unsystematic, and it hinders obtaining reliable results. Ilyash et al. (2020), Kasahara \& Lapham (2013), Roy \& Saggi (2012) prove that using situational modeling explains complicated, non-linear dependencies and the solution of the dimension problem. Such characteristics are typical of the state and tendencies of import dependency and, therefore, need analytical research and exact prognosis. A number of scientists support the use of multidimensional statistical analysis to assess import dependency. They believe it has no subjective characteristics and can precisely determine the tendencies of import dependency increase. Havlovska et al. (2019), Simeon et al. (2017) stress normative approval of the procedures for statistical analysis software, which eradicates different and inaccurate treatment of separate aspects of import dependency. It is known that using only available statistical quantitative information is not enough to assess import dependency. That is why we need to employ the procedure of synthesis of plurality of its characteristics (criteria). Therefore, we prove the relevance of the import dependency integral coefficient calculation, which is done on the basis of separate indicators characterizing the volume of domestic production, export, import, domestic consumption and foreign economic activity using modern analysis to economic mathematical modeling of the state economic security. Thus, it is possible to give a complex characteristic of the import dependency problem as well as determine a number of strategic steps of the state import replacement policy. Nowadays there is a negative influence of import dependency on providing and maintaining parameters of the state economic security. Reaching its critical value, it can lead to complete ousting of whole branch sectors of the national economy from the market, which is an important argument for forming and realizing state policy of import replacement. Shevchuk et al. (2019) and Rodrigues (2010) claim that the state economic security is a multi-factor category which characterizes the ability of the national economy for advanced reproduction aimed at satisfying the needs of its own population on a given level and resisting destabilizing action of the factors which threaten its stable balanced development; providing solvency of the national economy within the world economy system. Blaum et al. (2019) and Dana (2013) view state economic security as a system of economic relations, which is based on the mechanism of sequencing economic interests of business entities. This enables them to settle economic conflicts with the least loss and provide independence, stability, development, adaptability and inertia of the national economy in its interaction with domestic and foreign environments. Vlasyuk (2016) regards state economic security as the ability of the national economy to provide free, independent development and maintain the stability of the civil society and its institutions, adequate defense potential under any unfavorable conditions and scenarios; the ability of the state to protect national economic interests from foreign and domestic threats. Varnaliy, Onishchenko \& Masliy (2016) underline that state economic security must be provided first and foremost with the development of the economy itself, but not only with market mechanisms of self-regulation. The experience of economically developed countries proves that the dependence on import commodities can be temporary. The state, with the help of effective import replacement policy, can succeed in producing the commodities necessary for the market and become an exporter country. That is why within the research of import dependency and its influence on the state economic security we need to concentrate attention on the general factors which caused such state of the national economy and research the domestic market tendencies according to them. It adds to the practical value of using integral methodologies based on the representation of separate situations. 


\section{Methodology}

\subsection{Substantiation of the methodical sequence of import dependence assessment}

In the economic literature there is a wide arsenal of methodological analysis to the study of complex economic phenomena, including import dependency, using various indicators, the calculation results of which form conclusions about the level and structural characteristics of import dependency. However, there is a detachment of methodological analysis to evaluating import dependency on, firstly, relationships and the extent of its impact on the parameters of the state's economic security and, secondly, the formation of an effective process of strategizing the state policy of import substitution and strengthening the country's economic security. Therefore, a more qualitative methodical sequence looks like in Fig. 1. Mostly, while evaluating import dependency the following coefficients are used: import and export coverage, import quota, the GDP lead over import, and others, the values and characteristics of which serve as the basis for the analysis and formation of an information and analytical base in the field of the state policy of import substitution (Blaum et al., 2019; Simeon et al., 2017; Ramanarayanan, 2017).

\subsection{Approach to integrated assessment of import dependence}

For the purpose of the integral estimation of the economy's import dependency, it is offered to use the methodology, which consists in: the application of the multiplicative form of an integral index, which characterizes the studied dependencies by nonlinear relations, which are more inherent in economic processes and phenomena along with simpler linear ones; the possibility of simultaneous normalization and integral evaluation of indicators and their thresholds values; the formalized substantiation of weighted coefficients. According to this methodological approach, the integral index of import dependency $\left(I_{I D}\right)$ is calculated as follows:

$$
I_{I D}=\prod_{i=1}^{n} z_{i}^{a_{i}}, \sum_{i=1}^{n} a_{i}=1, a_{i} \geq 0
$$

where $z_{i}$ is the normalized values of $i$-indicators; $a_{i}$ is the weighted coefficients of $i$-indicators; $n$ is the number of indicators. The procedure of the normalization of indicators of the economy's import dependency can be carried out in two ways, in particular according to formula (2) the normalization is caused by the indicators' divergence (stimulants, de-stimulants).

$$
z_{i}=\left\{\begin{array}{l}
\frac{x_{i}}{x_{\max }}, \text { if } x_{i} \in S \\
\frac{x_{\min }}{x_{i}}, \text { if } x_{i} \in D
\end{array}\right.
$$

where $x_{i}$ is the actual values of $i$-indicators; $x_{\max }, x_{\min }$ are maximum and minimum of the actual indicators' values; $S$ is a set of values of the indicators that are stimulants; $D$ is a set of values of the indicators that are de-stimulants. According to another method, the normalized values of the indicators of the economy's import dependency are calculated as follows:

$$
\begin{aligned}
& \frac{x_{i}-x_{v}^{l}}{x_{t}^{l}-x_{v}^{l}} \Rightarrow x_{v}^{l} \leq x_{i}<x_{t}^{l} \\
& \frac{\left(x_{i}-x_{t}^{l}\right)+b \times\left(x_{o}^{\min }-x_{i}\right)}{x_{o}^{\min }-x_{t}^{l}} \Rightarrow x_{t}^{l} \leq x_{i}<x_{o}^{\max } \text {; } \\
& z_{i}=\left\{1, \quad x_{o}^{\min } \leq x_{i} \leq x_{o}^{\max } ;\right. \\
& \frac{b \times\left(x_{i}-x_{o}^{\max }\right)+\left(x_{t}^{h}-x_{i}\right)}{x_{t}^{h}-x_{o}^{\max }} \Rightarrow x_{o}^{\max }\left\langle x_{i} \leq x_{t}^{h}\right. \text {; } \\
& \frac{x_{v}^{h}-x_{i}}{x_{v}^{h}-x_{t}^{h}} \Rightarrow x_{t}^{h}\left\langle x_{i}<x_{v}^{h}\right. \text {. }
\end{aligned}
$$


where $x_{t}^{h}, x_{t}^{l}$ are $t$-threshold $h$-upper and $l$-lower value of the indicator (it is recommended not to cross); $x_{o}^{\max }, x_{o}^{\min }$ are $o$ optimal max-maximum and min-minimum value of the indicator; $x_{v}^{h}, x_{v}^{l}$ are $v$-limit $h$-upper and $l$-lower value of the indicator; $b$ is the coefficient of the standardization of regression dependencies $(b=0.5)$.

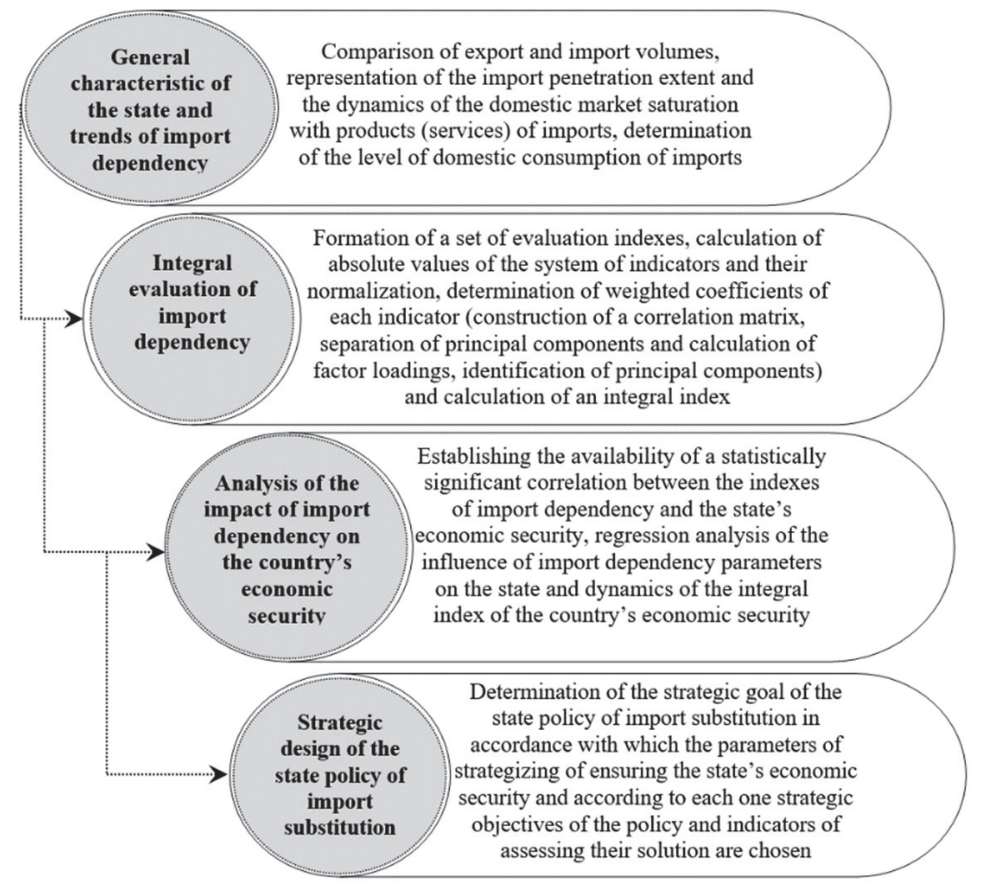

Fig. 1. Methodical sequence of the evaluation of import dependency, its impact on the state's economic security and Source: authors' elaboration strategizing the import substitution state management

\subsection{Determination of weights}

An important element of the analysis methodology is the justification of indicators' weighted coefficients and their groups. Expert evaluations are often used to determine weighted coefficients, in particular, the method of paired comparisons, which are largely subjective as they are based on experts' partial intuitive assumption on the development of the phenomena under study without their specific formalization. Therefore, it is advisable to determine the significance (weight) of the indicators of the economy's import dependency using Hotelling's method of transformation (the method of orthogonal projection or principal components), which eliminates excessive subjectivism. In the orthogonal model of principal components, the relationship between primary features and components is described by the following relationship:

$$
y_{i}=\sum_{i=1}^{m} c_{i} \times K_{i}
$$

where $y_{i}$ is the standardized values of $i$-component with single dispersions (total dispersion is equal to the number of features $m) ; c_{i}$ is the contribution of $i$-component to the total dispersion of the set of indicators; $K_{i}$ is the value of $i$-component, which is defined as follows:

$$
K_{i}=\sum_{i=1}^{m} d_{i} \times n_{i}
$$

where $d_{i}$ is factor loadings; $n_{i}$ is input data. In turn, the weighted coefficients of the indicators $\left(a_{i}\right)$ are determined by the formula:

$$
a_{i}=\frac{c_{i}\left|d_{i}\right|}{\sum_{i=1}^{m} c_{i}\left|d_{i}\right|}
$$

The application of the method of principal components also requires centering (formula (7)) or normalization (formula (8)) of the offered set of indicators, since the magnitudes of their dispersions depend significantly on the scale of measuring the economy's import dependency: 
$X_{i}^{G}=\frac{x_{1 i}+\ldots+x_{G i}}{G}$,

where $X_{i}^{G}$ is the projection of centered $i$-indicator in their total $G$-set; $x_{i}$ is the actual values of $i$-indicators.

$$
R_{i}=\sqrt{\frac{\sum_{i=1}^{G}\left(x_{i}-X_{i}^{G}\right)^{2}}{G}},
$$

where $R_{i}$ is the normalized value of $i$-indicator. In particular, using these methodological provisions, the weighted coefficients of the indicators of the integral index of Ukraine's import dependency are calculated (Table 1).

\section{Table 1}

Weighted coefficients of the indicators of the integral index of the import dependency of Ukraine's economy

\begin{tabular}{l} 
Indicators \\
Share of imports in domestic consumption \\
Import quota \\
Coefficient of the GDP lead over imports \\
Share of goods manufactured in the territory of Ukraine in the structure of retail trade turnover of enterprises \\
Share of the sale of goods of Ukrainian production in the structure of wholesale turnover of wholesale trade enterprises \\
Coefficient of export coverage of the import of goods and services \\
Growth rate of the import of goods and services in national currency (by chain approach) \\
\hline Source:
\end{tabular}

Source: own research results

\subsection{Approach to the interpretation of results}

In order to interpret the results of integral evaluation of the economy's import dependency, it is advisable to use Harrington's scale, which consists of five interval estimates of the value of an integral indicator (Table 2).

\section{Table 2}

Harrington's interval scale to interpret the values of the integral index of import dependency

\begin{tabular}{ccc}
$\begin{array}{c}\text { Integral levels of import } \\
\text { dependency }\end{array}$ & $\begin{array}{c}\text { Intervals of numerical values of the } \\
\text { integral index of import dependency }\end{array}$ & Characteristics of import dependency \\
\hline $\begin{array}{c}\text { Very high } \\
\text { High }\end{array}$ & $0.80-1.00$ & $\begin{array}{l}\text { Systematic penetration of significant volumes of imports into all aspects of } \\
\text { the domestic market, critical increase in the competitiveness and demand for } \\
\text { imported products (services) }\end{array}$ \\
\hline Moderate & $0.63-0.80$ & $\begin{array}{l}\text { Increasing the import volume and insufficiently considered national policy of } \\
\text { supporting domestic production }\end{array}$ \\
\hline Low & $0.37-0.63$ & $\begin{array}{l}\text { Changes in structural characteristics of domestic consumption, production, } \\
\text { distribution and circulation of goods in favor of imports }\end{array}$ \\
\hline Very low & $0.20-0.37$ & $0.00-0.20$
\end{tabular}

\section{Source: own research results}

\section{Results and Discussion}

\subsection{Characteristic of the status and trends of Ukraine's import dependency}

For Ukraine's economy, the strengthening of import dependency is a modern, clearly marked trend that emerged immediately after proclaiming independence and establishing market relations. The negative point is that the situation is worsening every year, especially in those industries where there are all the prerequisites for the growth in domestic production similar to imports (Havlovska et al., 2019; Vasyltsiv, \& Lupak, 2016; Varnaliy et al., 2016). In Ukraine, there is the situation when flows of imported goods without any obstacles and counteractions enter the domestic market. Moreover, the increase in import dependency is exacerbated by the aggravation of the military-political situation inside the country, the reduction of foreign direct investment, the shadowing of the business environment, and the deformation of population consumer needs. It is worth mentioning the high energy intensity of production processes, the depreciated state of fixed assets, the deterioration of innovation and technological potential, the inefficient use of budget funds that are directed to support the economy's sectors (Kutsyk et al., 2020; Semiv, \& Semiv, 2017; Vlasiuk, 2016; Vasyltsiv et al. 2020). In 2005-2018, the share of Ukrainian goods sales decreased from $70.5 \%$ to $53.2 \%$ (by 17.3 ), the average annual growth rate of imports was $17.8 \%$ and exceeded the growth rate of Ukrainian goods sale, the share of imports in domestic consumption exceeded $50.0 \%$, the share of imports in the GDP in some periods reached $60.0 \%$, the exports covered the imports on average by no more than $90.0 \%$ annually, and the lead of imports over exports was more than 3.0\% (State Statistics Service of Ukraine, 2020) (Table 3). 


\section{Table 3}

Absolute values of the indicators of Ukraine's import dependency in 2005, 2008-2018

\begin{tabular}{|c|c|c|c|c|c|c|c|c|c|c|c|c|c|c|}
\hline \multirow{2}{*}{ Indicators } & \multicolumn{12}{|c|}{ Years } & \multicolumn{2}{|c|}{$\begin{array}{c}\text { Absolute } \\
\text { deviations, } \pm\end{array}$} \\
\hline & 2005 & 2008 & 2009 & 2010 & 2011 & 2012 & 2013 & 2014 & 2015 & 2016 & 2017 & 2018 & $\begin{array}{c}2018 / \\
2005\end{array}$ & $\begin{array}{c}2018 / \\
2017 \\
\end{array}$ \\
\hline $\begin{array}{l}\text { Share of imports in domestic } \\
\text { consumption, \% }\end{array}$ & 58.1 & 57.9 & 54.1 & 58.9 & 65.7 & 60.6 & 55.2 & 57.5 & 62.8 & 61.4 & 62.3 & 62.9 & 4.8 & 0.6 \\
\hline Import quota, $\%$ & 50.6 & 54.9 & 48.1 & 53.7 & 60.6 & 57.2 & 52.9 & 52.1 & 54.5 & 56.2 & 57.1 & 57.7 & 7.1 & 0.6 \\
\hline $\begin{array}{l}\text { Coefficient of the GDP lead over } \\
\text { imports }\end{array}$ & 1.10 & 0.92 & 1.14 & 0.90 & 0.89 & 1.06 & 1.08 & 1.02 & 0.96 & 0.97 & 0.95 & 0.96 & -0.15 & 0.01 \\
\hline $\begin{array}{l}\text { Share of goods manufactured in the } \\
\text { territory of Ukraine in the structure of } \\
\text { retail trade turnover of enterprises, } \%\end{array}$ & 70.5 & 63.1 & 67.4 & 64.3 & 61.9 & 58.9 & 57.2 & 57.8 & 58.1 & 55.8 & 52.3 & 53.2 & -17.3 & 0.9 \\
\hline $\begin{array}{l}\text { Share of the sale of goods of Ukrainian } \\
\text { production in the structure of wholesale } \\
\text { trade turnover of enterprises, \% }\end{array}$ & 71.8 & 65.6 & 66.8 & 66.5 & 63.9 & 58.9 & 54.3 & 48.5 & 46.9 & 44.6 & 43.7 & 42.0 & -29.8 & -1.7 \\
\hline $\begin{array}{l}\text { Coefficient of export coverage of the } \\
\text { import of goods and services }\end{array}$ & 1.03 & 0.86 & 0.97 & 0.95 & 0.93 & 0.90 & 0.90 & 1.06 & 1.09 & 1.01 & 0.87 & 0.83 & -0.20 & -0.04 \\
\hline $\begin{array}{l}\text { Growth rate of the import of goods and } \\
\text { services in national currency (by chain } \\
\text { approach), } \%\end{array}$ & 115.8 & 142.9 & 84.3 & 132.4 & 135.8 & 105.7 & 96.6 & 102.6 & 131.1 & 123.7 & 115.1 & 122.1 & 6.3 & 7.0 \\
\hline
\end{tabular}

Source: own research results

At the present stage of the development of the Ukrainian economy, there is the situation where the influence of factors stimulating an increase in the imports of goods has strengthened (in particular, the domestic market capacity has expanded (in 2018 compared to the corresponding period of the previous year, the retail and wholesale turnover of the enterprises increased by $5.6 \%$ and $3.3 \%$ respectively), real incomes of the population have increased (by 12.5\%), production and trade and distribution infrastructures are developing, the chances of goods to enter the internal system of goods and services turnover are improving, while the economic and administrative system of its counteraction including the tools of formation and use of the domestic production capacity, the implementation of the national strategy to ensure production technological competitiveness, the adoption of international practices combating the shadow economy is not formed yet. Despite the positive economic trends, Ukrainian producers are still unable to win the competition and to fully meet population consumer needs, although they have sufficient production potential. This is confirmed by a faster growth of the domestic market capacity compared to the volume of the economic activity of Ukrainian producers, which leads to a further increase in the share of goods manufactured outside Ukraine in the structure of retail turnover (up to more than $50.0 \%$ ). Therefore, there are reasons to affirm the prerequisites for maintaining the tendency to increase the negative surplus of foreign trade balance and stable formation of an import-dependent consumer model of the economy (Shevchuk et al., 2019).

\subsection{Discussing the elasticity of Ukraine's import dependency and economic security relations: empirical characteristics}

The problem of import dependency of the Ukrainian economy has become one of the factors of weakening of its economic security, the parameters of which at the present stage of the country's socio-economic development are not high and continue to worsen. During 2010-2018 there was an unsatisfactory level of the integral index of the state's economic security (Fig. 2). Herewith, the coefficient of determination between the indexes of import dependency and the state's economic security was 0.7645 , which indicates that there was a close connection between them. The lower values of import substitution parameters with the higher value of economic security indicators and vice versa are clearly observed. Obviously, the prerequisites for such a state of affairs were caused by the ill-considered openness policy, which was implemented at the post-transformational stage of the development of the state's national economy, the reduction in the competitiveness of domestic producers and their products, the population business activity, as well as the institutional support for basic economic activity entities.

The value of the integral index of Ukraine's economic security is influenced by a significant number of qualitative and quantitative factors, the impact of which is estimated using statistical methods. Herewith, the tools of multifactor dynamic regression modeling, in particular, dynamic balance cross-sectional regression for the regions of Ukraine during 2010-2018, were used to identify the factors of influence on the level of the state's economic security (dependent variable), which allows forming a large-scale general sample (3,024 observations). The indexes of import dependency of Ukraine's regions were selected as independent variables. The results of determining the regression dependency of economic security and import dependency are statistically significant, as evidenced by the relevant indicators (correlation coefficient is 0.8962 ; the adjusted coefficient of determination is 0.7989 ; Fisher $F$-test $F(5.144)$ is $10.775 ; \mathrm{p}<0.0000$; the indicator of the statistical error level is 10.220). It is established that the factors that have a positive impact on the economic security strengthening are the coefficient of the GDP lead over imports (regression coefficient is 0.3602), the share of goods manufactured in the territory of Ukraine in 
the structure of retail trade turnover of enterprises $(0.3509)$ and the share of the sale of goods of Ukrainian production in the structure of wholesale trade turnover of enterprises (0.1277) (Table 4).

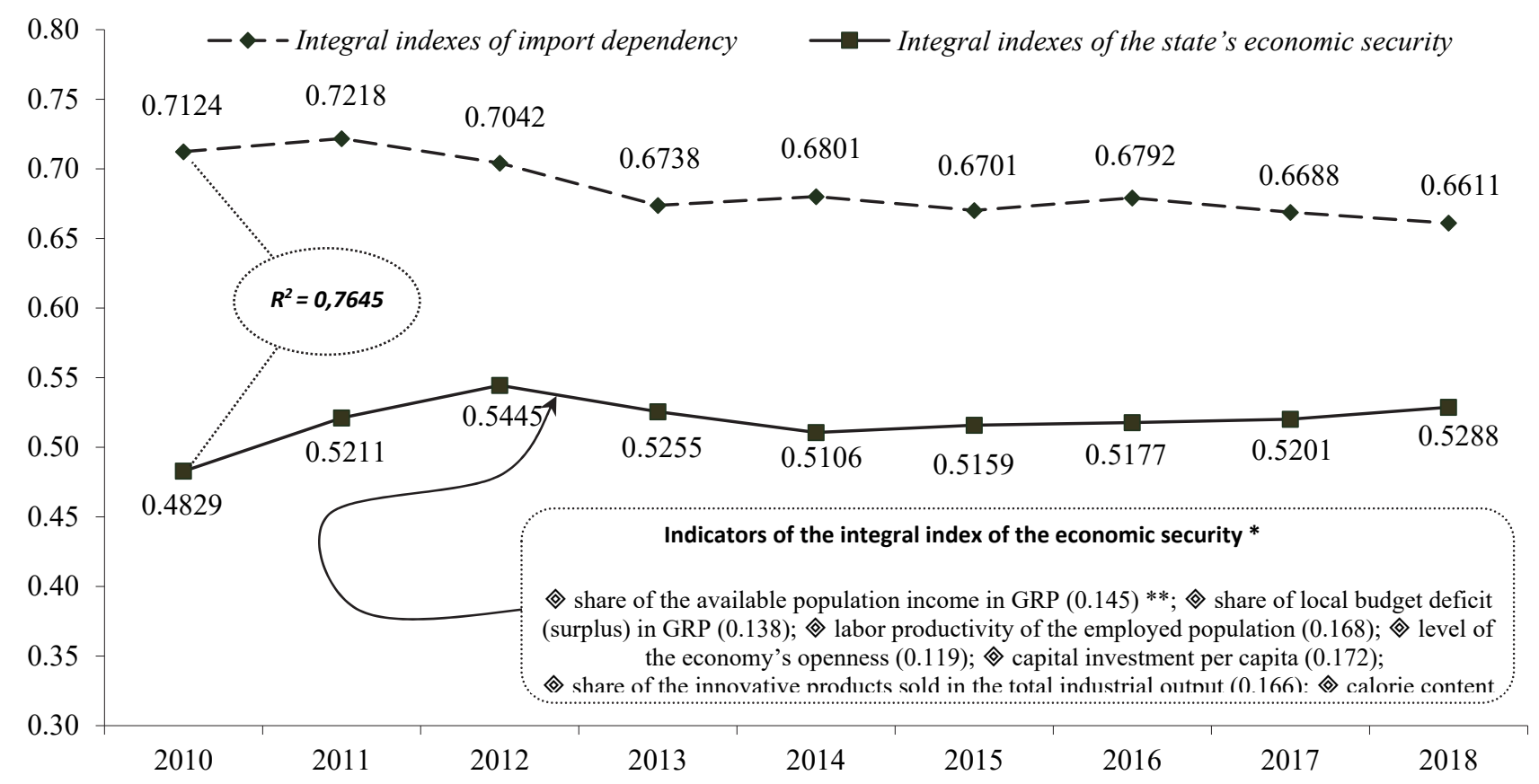

* integral index of the state's economic security is calculated according to the offered methodological scheme for the integral evaluation of import dependency;

** coefficients of the significance (weight) of the indicators of the integral index of the state's economic security

Fig. 2. Graphical interpretation of the integral indexes of import dependency and Ukraine's economic security in $2010-2018$

Source: authors' elaboration

\section{Table 4}

Information on the results of the regression analysis of the impact of import dependency indicators on Ukraine's economic security in 2010-2018

\begin{tabular}{|c|c|c|c|c|c|c|}
\hline \multirow{2}{*}{ Factors } & \multicolumn{6}{|c|}{ Characteristics of the analysis results } \\
\hline & Beta & Std. Err. & $B$ & Std.Err. & $t(144)$ & p-level \\
\hline Free member & - & - & 84.3571 & 9.2916 & 9.0789 & 0.0000 \\
\hline Share of imports in domestic consumption, $\%$ & -0.2201 & 0.0870 & 0.0892 & 0.0337 & 2.6441 & 0.0091 \\
\hline Import quota, $\%$ & -0.1954 & 0.0747 & 0.0791 & 0.0280 & 2.0531 & 0.0055 \\
\hline Coefficient of the GDP lead over imports, $\%$ & 0.3602 & 0.0955 & -0.1461 & 0.1017 & -2.7821 & 0.0003 \\
\hline $\begin{array}{l}\text { Share of goods manufactured in the territory of Ukraine in the } \\
\text { structure of retail trade turnover of enterprises, } \%\end{array}$ & 0.3509 & 0.0904 & -0.6047 & 0.1603 & -3.7723 & 0.0002 \\
\hline $\begin{array}{l}\text { Share of the sale of goods of Ukrainian production in the structure of } \\
\text { wholesale trade turnover of enterprises, } \%\end{array}$ & 0.1207 & 0.1004 & -0.0762 & 0.0616 & -1.2368 & 0.0021 \\
\hline Coefficient of export coverage of the import of goods and services, $\%$ & -0.1807 & 0.1007 & 0.0241 & 0.0135 & 1.7837 & 0.0766 \\
\hline $\begin{array}{l}\text { Growth rate of the import of goods and services in national currency } \\
\text { (by chain approach), \% }\end{array}$ & -0.1406 & 0.0836 & 0.0519 & 0.0298 & 1.7429 & 0.0834 \\
\hline
\end{tabular}

Source: own research results

The inverse proportional relationship is attributed to the factors such as the share of imports in domestic consumption (-0.2201), the import quota $(-0.195)$ and the growth rate of an increase in the imports of goods $(-0.1406)$. This is due to the fact that the aggressive expansion of imports caused the deformation of the Ukrainian manufacturing sector and export potential. In some years, the imports exceeded half of the country's GDP. It is obvious that a further increase in the imports share in domestic consumption will only increase threats to Ukraine's economic security. The results of analyzing the relationship between economic security and the coefficient of export coverage of imports are of applied significance. In particular, with an increase in the export coverage ratio of imports of $1.0 \%$, the level of economic security decreases by $0.18 \%$. This situation can be explained by the fact that maintaining a high export orientation of Ukrainian producers in the conditions of insufficient realization of potential in the domestic market frees up a significant niche for import expansion. At the same time, national producers manufacture a significant amount of output for exports with low added value, so the value of the export coverage ratio of imports in physical volumes remains at a very high level. Herewith, in the domestic market, consumer demand generates needs for high added value goods that are satisfied by importers. 


\subsection{Strategic guidelines for the import substitution state management and ensuring the country's economic security}

A close link between the problems of Ukraine's import dependency and economic security leads to the conclusion about the benefits and need for coordinated government policymaking in these two areas. The systemic impact of the import substitution policy on strengthening the state's economic security is ensured by the coordination of the strategic priorities of import substitution with the basic parameters of economic security according to the descriptive model:

$$
S D I M=\uparrow K+\Theta S M+\uparrow I R M+U C R E+\Leftrightarrow L D M,
$$

where SDIM is the country's economic security; $K$ is the volumes of economic activity and capital; $S M$ is the main structural characteristics of the economy's functioning; IRM is a measure of penetration of innovations and innovative development of the stages of public reproduction of the economy (production, distribution, exchange, consumption); $C R E$ is the quality of the formed competitive and regulatory environment; $L D M$ is the level of differentiation of the development of economic sectors, their infrastructure and resources. It is undoubted that the main efforts of public authorities in ensuring the state's economic security should be directed to the successful implementation of the import substitution policy through the relevant state strategic programming documents. At the same time, the goal of the state import substitution policy in Ukraine is to determine the reduction of the economy's dependence on imports due to competitiveness strengthening and an increase in the demand for goods (works, services) of Ukrainian production, production capacity building and realization of the country's investment and innovation potential (Fig. 3).

\subsection{Tendencies of institutional changes and structural reforms in the context of the implementation of the import substitution public administration}

Achieving the strategic goal and objectives of the import substitution state policy in Ukraine implies the realization of agreed institutional and structural measures, taking into account regional and sectoral special features. In the direction of institutional changes, it is necessary to improve the regulatory and methodological basis, introduce spatial and territorial strategic planning and programming, improve institutional and organizational principles for the implementation of the import substitution regional policy; in the sectoral aspect, a state policy should concern the improvement of the institutional support and promotion of the development of infrastructure networks for the development of enterprises of high-tech industries, the promotion of institutional and organizational development of vertically-functional integration of enterprises in the fields of production and trade, the guarantee of cross-sectoral and inter-sectoral cooperation, the development of the system of institutions for promoting and popularization of the products of economy's basic industries. Structural reforms should focus on increasing the number and expansion of the market share of retail outlets for the sale of locally produced goods, streamlining of the spatial and specific structure, and improving the system of resource guarantee of import substitution production, ensuring the goods movement of import flows only through legal and organized trade outlets, increasing the share of high- added-value-innovative and technological products, the improvement of inter-functional coordination parameters and the interaction between producers of import substituting goods and business entities of the intermediary infrastructure. In the process of institutional and structural reforms in the planning and implementation of the import substitution state policy, it is important to take into account external factors and tendencies, which are caused by the modern reorientation and change of the strategic vector of foreign economic relations (to European integration). In the short and medium term, this necessitates both the need to be prepared for the competition by Ukrainian enterprises with more competitive external entities in the more open domestic market and the expansion of the competition "field" to the European space.

\section{Conclusions}

There are a sufficient number of methodological analyses to assess the economy's import dependency. Mainly, the coefficients of export coverage of imports, the import quota, the GDP lead over imports and others are used. Their analysis is the informational and analytical basis of the formation of the import substitution state policy. However, the available methodological analysis is inconsistent with the evaluation of the relations and extent of the impact of import dependency on the country's economic security parameters, and it is not a sufficient information and analytical basis to form an effective process of strategizing the import substitution state policy and strengthening the country's economic security. The results of the integrated evaluation of the import dependency of the Ukrainian economy indicate its critically high level. At the same time, there is a significant impact of import dependency on the state's economic security (the coefficient of determination between the integral indexes was 0.7645). This is because in the economy of Ukraine economic tools to counteract the expansion of imports are not introduced, but, instead, the influence of factors that stimulate a further increase in import dependency increases. The high import dependency is caused by insufficient state regulation in this area. In view of this, the strategic priorities of the import substitution state policy concern: the expansion of the domestic market capacity by consuming competitive Ukrainian goods, and the formation of investment support for technical and technological modernization of the Ukrainian production; the formation of optimal structural relationships in the segments of production and marketing of goods; ensuring high innovation activity in the economy's real sector; forming a quality business environment; the realization of the potential of import substitution in strengthening the spatial and structural competitiveness of territories and segments of the economy. 


\begin{tabular}{|c|c|c|}
\hline $\begin{array}{l}\text { Strategic goal of the } \\
\text { import substitution state } \\
\text { management policy: }\end{array}$ & \multicolumn{2}{|c|}{$\begin{array}{l}\text { Decrease of the economy's dependency on import due to competitiveness strengthening and an } \\
\text { increase in the demand for goods (products, services) of domestic production, production } \\
\text { capacity building and realization of innovative potential }\end{array}$} \\
\hline$\downarrow$ & & \\
\hline $\begin{array}{l}\text { Parameters for ensuring the } \\
\text { country's economic security }\end{array}$ & $\begin{array}{l}\text { Strategic priorities of the import } \\
\text { substitution state policy: }\end{array}$ & $\begin{array}{c}\text { Indicators of the implementation of } \\
\text { strategic priorities }\end{array}$ \\
\hline & - & 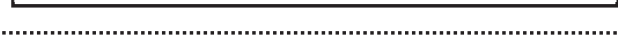 \\
\hline $\begin{array}{l}\text { Expanded reproduction of } \\
\text { the volumes of economic } \\
\text { activity and capital in } \\
\text { economy's basic sectors }\end{array}$ & $\begin{array}{l}\text { Expansion of the domestic market } \\
\text { capacity due to the consumption of } \\
\text { domestic and high-quality competitive } \\
\text { goods (products, services). Formation } \\
\text { of investment support for technical and } \\
\text { technological modernization of } \\
\text { domestic production }\end{array}$ & $\begin{array}{l}\diamond \text { volumes of retail and wholesale turnover of } \\
\text { goods (products, services) of domestic } \\
\text { production per unit of population and resources; } \\
\diamond \text { number of trade objects with specialization } \\
\text { on the sale of goods of domestic production; } \\
\diamond \text { volumes of tangible and intangible assets of } \\
\text { domestic enterprises; } \\
\diamond \text { share of investments in the value of fixed } \\
\text { assets of domestic entities in the economy's real } \\
\text { sector }\end{array}$ \\
\hline $\begin{array}{l}\text { Rational relations of key } \\
\text { structural characteristics of } \\
\text { the economy's functioning }\end{array}$ & $\begin{array}{l}\text { Formation of optimal structural } \\
\text { relationships in the segments of } \\
\text { production and sales of goods } \\
\text { (products, services) in the domestic } \\
\text { market }\end{array}$ & $\begin{array}{l}\otimes \text { share of the sales of consumer goods } \\
\text { produced in Ukraine; } \\
\diamond \text { share of sold innovative products of } \\
\text { domestic production; } \\
\otimes \text { share of the sales of goods that are regional } \\
\text { (local) brands or trademarks; } \\
\diamond \text { share of the sales of products by domestic } \\
\text { small business entities }\end{array}$ \\
\hline $\begin{array}{l}\text { Innovative development of } \\
\text { the stages of social } \\
\text { reproduction (production, } \\
\text { distribution, exchange, } \\
\text { consumption) }\end{array}$ & $\begin{array}{l}\text { Ensuring high innovation activity } \\
\text { in the economy's real sector }\end{array}$ & $\begin{array}{l}\diamond \text { number and share of domestic enterprises } \\
\text { implementing innovations; } \\
\diamond \text { share of the sales of high-added-value domestic } \\
\text { innovative and technological products; } \\
\diamond \text { share of domestic goods in the product range of } \\
\text { retail chains; } \\
\diamond \text { share of the cost of innovation in the cost price } \\
\text { of domestic products; } \\
\diamond \text { share of high-quality and safe goods of } \\
\text { domestic production in the total volume of } \\
\text { commodity consumption }\end{array}$ \\
\hline $\begin{array}{l}\text { Compliance with basic } \\
\text { conditions of the } \\
\text { competitive and regulatory } \\
\text { environment }\end{array}$ & $\begin{array}{l}\text { Formation of a quality business } \\
\text { environment in the domestic market }\end{array}$ & $\begin{array}{l}\Leftrightarrow \text { qualitative characteristics of labor and cost } \\
\text { capacity of licensing, permitting and approval } \\
\text { procedures for the opening (development) of } \\
\text { production; } \\
\Leftrightarrow \text { number and volumes of activities of integrated and } \\
\text { cluster structures; } \\
\diamond \text { availability and volumes of investment at } \\
\text { investment sites }\end{array}$ \\
\hline $\begin{array}{l}\text { Balancing the domestic } \\
\text { market segments, their } \\
\text { infrastructure and resource } \\
\text { guarantee }\end{array}$ & $\begin{array}{l}\text { Implementation of the potential of } \\
\text { import substitution in strengthening } \\
\text { the spatial and structural } \\
\text { competitiveness of territories and } \\
\text { segments of the economy }\end{array}$ & $\begin{array}{l}\text { Differentiation in the domestic market } \\
\text { development by regions, in urban and rural } \\
\text { settlements in relation to: } \\
\diamond \text { volumes of domestic goods consumption } \\
\text { (products, services) per capita; } \\
\diamond \text { number of trade objects per capita; } \\
\diamond \text { volume of retail area per capita; } \\
\diamond \text { commodity specialization of the retail trade } \\
\text { network; }\end{array}$ \\
\hline
\end{tabular}

Fig. 3. Characteristics of the strategy of the implementation of import substitution management policy and ensuring the country's economic security Source: authors' elaboration 


\section{References}

Blaum, J., Lelarge, C., \& Peters, M. (2019). Firm size, quality bias and import demand. Journal of International Economics, 120(1), 59-83. https://doi.org/10.1016/j.jinteco.2019.04.004.

Cook, S. A., \& Watson, Ph. (2011). Comparison of Regional Export Enhancement and Import Substitution Economic Development Strategies. The Journal of Regional Analysis and Policy, 41(1), 1-15.

Dana, J. (2013). Market-based approaches for governments of food-importing countries to manage food security risks. Global Food Security, 2(1), 182-187. https://doi.org/10.1016/j.gfs.2013.06.001.

Felbermayr, G., Jungc, B., \& Larchc, M. (2015). The welfare consequences of import tariffs: A quantitative perspective. Journal of International Economics, 97(2), 295-309. https://doi.org/10.1016/j.jinteco.2015.05.002.

Günçavd, Ö., \& Ülengin, B. (2017). Tradable and non-tradable expenditure and aggregate demand for imports in an emerging market economy. Economic Systems, 41(3), 445-555. https://doi.org/10.1016/j.ecosys.2016.10.006.

Havlovska, N., Pokotylova, V., Korpan, O., Rudnichenko, Ye., \& Sokyrnyk, I. (2019). Modeling of the process of functioning of the mechanism of economic security of foreign economic activity of enterprise taking into account weak signals and identification of risks and threats. International Journal of Scientific \& Technology Research, 8(12), $2216-2522$.

Hrynkevych, S.S., Vasyltsiv, T.H. (2015). Systemic transformation of National labor potential. Actual Problems of Economics, 167(5), pp. 356-364.

Ilyash, O., Dzhadan, I., \& Ostasz, G. (2018). The influence of the industry's innovation activities indices on the industrial products' revenue of Ukraine. Economics and Sociology, 11(4), 317-331. https://oi.org/10.14254/2071-789X.2018/11-4/21.

Ilyash, O., Yildirim, O., Doroshkevych, D., Smoliar, L., Vasyltsiv, T., \& Lupak R. (2020) Evaluation of enterprise investment attractiveness under circumstances of economic development. Bulletin of Geography. Socio-economic Series, 47, 95-113.

Kasahara, H., \& Lapham, B. (2013). Productivity and the decision to import and export: Theory and evidence. Journal of International Economics, 89(2), 297-316. https://doi.org/10.1016/j.jinteco.2012.08.005.

Kutsyk, P., Lupak, R., Kutsyk, V., \& Protsykevych, A. (2020). State policy of the investment processes development on the market of IT services: Analytical and strategic aspects of Implementation in Ukraine. Economic Annals-XXI, 182(3-4), 64-76.

Liu, R., \& Rosell, C. (2013). Import competition, multi-product firms, and basic innovation. Journal of International Economics, 91(2), 220-234. https://doi.org/10.1016/j.jinteco.2013.08.004.

Ramanarayanan, A. (2017). Imported inputs, irreversibility, and international trade dynamics. Journal of International Economics, 104, 1-18. https://doi.org/10.1016/j.jinteco.2016.10.007.

Ramanarayanan, A. (2020). Imported inputs and the gains from trade. Journal of International Economics, 122, 51-65.

Rodrigues, M. (2010). Import substitution and economic growth. Journal of Monetary Economics, 57, $175-188$.

Roy, S., \& Saggi, K. (2012). Equilibrium parallel import policies and international market structure. Journal of International Economics, 87(2), 262-276. https://doi.org/10.1016/j.jinteco.2012.01.007.

Shevchuk, V. O., Synchak, V., Zaverbnyj, A. S., \& Baranetska, O. V. (2019). Determinants of the current account balance and output in Ukraine. Financial and credit activity: problems of theory and practice, 30(1), 186-195.

Simeon, K., Masudul, H. M., \& Manitra, R. (2017). Analysis of Food Imports in a Highly Import Dependent Economy. Review of Middle East Economics and Finance, 13(2), 1-12.

State Statistics Service of Ukraine (2020). Official web-site. Retrieved from http://www.ukrstat.gov.ua.

Varnaliy, Z., Onishchenko, S., \& Masliy, A. (2016). Threat prevention mechanisms of Ukraine's economic security. Economic Annals-XXI, 159(5-6), 20-24. https://doi.org/10.21003/ea.V159-04.

Vasyltsiv, T., \& Lupak R. (2016). Strategic priorities of state structural policy of import substitution in Ukraine. Actual Problems of Economics. 1(175). P. 52-60.

Vasyltsiv, T., Irtyshcheva, I., Lupak, R., Popadynets, N., Shyshkova, Y., Boiko, Y., \& Ishchenko, O. (2020). Economy’s innovative technological competitiveness: Decomposition, methodic of analysis and priorities of public policy. Management Science Letters, 10(13), 3173-3182. https://doi.org/10.5267/j.msl.2020.5.004.

Vlasiuk, O. S. (2016). National security of Ukraine: evolution of domestic policy. Kyiv: National Institute for Strategic Studies.

Vlasiuk, O., Ilyash, O., Olszewski, W., Osinska, M., \& Voloshyn, V. (2016). System transformations of the national economy: challenges and expectations, vol. 1. Bydgoszcz: University of Economy Publishing House.

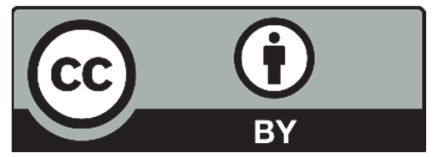

(C) 2021 by the authors; licensee Growing Science, Canada. This is an open access article distributed under the terms and conditions of the Creative Commons Attribution (CC-BY) license (http://creativecommons.org/licenses/by/4.0/). 